Article

\title{
Appraisal of Antiophidic Potential of Marine Sponges against Bothrops jararaca and Lachesis muta Venom
}

\section{Camila Nunes Faioli ${ }^{1}$, Thaisa Francielle Souza Domingos ${ }^{1,2}$, Eduardo Coriolano de Oliveira ${ }^{1}$, Eládio Flores Sanchez ${ }^{3}$, Suzi Ribeiro ${ }^{4}$, Guilherme Muricy ${ }^{4}$ and Andre Lopes Fuly ${ }^{1, *}$}

1 Department of Molecular and Cellular Biology, Institute of Biology, Federal Fluminense University, Niteroi 24020-141, RJ, Brazil; E-Mails: camilafaioli@hotmail.com (C.N.F.); thaisadomingos@yahoo.com.br (T.F.S.D.); eduardocoriolano@globo.com (E.C.O.)

2 Department of Marine Biology, Institute of Biology, Federal Fluminense University, Niteroi 24020-141, RJ, Brazil

3 Ezequiel Dias Foundation, Belo Horizonte 30510-010, MG, Brazil;

E-Mail: eladio@funed.mg.gov.br

4 Department of Invertebrates, Federal University of Rio de Janeiro, National Museum 20940-040, RJ, Brazil; E-Mails: suzimr@yahoo.com.br (S.R.); muricy@mn.ufrj.br (G.M.)

* Author to whom correspondence should be addressed; E-Mail: andfuly@vm.uff.br; Tel.: +55-21-2629-2294; Fax: +55-21-2629-2376.

Received: 2 August 2013; in revised form: 8 October 2013 / Accepted: 11 October 2013 / Published: 17 October 2013

\begin{abstract}
Snakebites are a health problem in many countries due to the high incidence of such accidents. Antivenom treatment has regularly been used for more than a century, however, this does not neutralize tissue damage and may even increase the severity and morbidity of accidents. Thus, it has been relevant to search for new strategies to improve antiserum therapy, and a variety of molecules from natural sources with antiophidian properties have been reported. In this paper, we analyzed the ability of ten extracts from marine sponges (Amphimedon viridis, Aplysina fulva, Chondrosia collectrix, Desmapsamma anchorata, Dysidea etheria, Hymeniacidon heliophila, Mycale angulosa, Petromica citrina, Polymastia janeirensis, and Tedania ignis) to inhibit the effects caused by Bothrops jararaca and Lachesis muta venom. All sponge extracts inhibited proteolysis and hemolysis induced by both snake venoms, except $H$. heliophila, which failed to inhibit any biological activity. P. citrina inhibited lethality, hemorrhage, plasma clotting, and hemolysis induced by B. jararaca or L. muta. Moreover, other sponges inhibited hemorrhage induced only by B. jararaca. We conclude that Brazilian sponges may be a
\end{abstract}


useful aid in the treatment of snakebites caused by L. muta and B. jararaca and therefore have potential for the discovery of molecules with antiophidian properties.

Keywords: Brazilian sponges; Bothrops jararaca; Lachesis muta; snake venom; neutralization

\section{Introduction}

Snakebite envenomation is an important public health problem in tropical, subtropical, and developing countries, and according to World Health Organization is a neglected disease [1]. Snake bite is estimated to affect more than five million people per year, with 100,000 death and around three times as many amputations or other disabilities; although the exact number of is unknown [1,2]. Snake venoms are composed of a complex mixture of enzymes and non-enzymatic proteins that interact and interfere with several systems of the body, affecting haemostasis and leading to pathophysiological disturbances. Envenomation by snakes causes systemic effects as well as local reactions in the region of the bite [3-5]. Systemic effects include neurotoxicity, cardiovascular, renal and respiratory symptoms, hemolysis, and hemorrhage; while locally there may be tissue necrosis causing permanent disability resulting in limb amputation, hemorrhage, edema, pain, and inflammatory reactions [6-8]. In South America, B. jararaca has a higher incidence of accidents (95\%) than L. muta (2\%), although L. muta bites lead to more severe symptoms and have a lethality index three times higher than B.jararaca [9].

Until now, snake antivenoms have been the only effective treatment able to counteract most of the symptoms that follow snakebites [1,9-11]. However, antivenoms have some disadvantages, as they may produce side effects (from mild fever to anaphylactic reactions), poorly inhibit local effects, and have high production costs [1,12-14]. The production of higher quality, safer, and cheaper antivenoms is a challenge worldwide. For this, it is important to search for molecules capable of neutralizing local effects more efficiently, and to use them together with antivenoms to complement the effectiveness of serum treatment.

The seas provide an amazing source of molecules when compared to the terrestrial environment. Among 34 phyla, 17 occur on land and 32 occur in the sea. Marine organisms produce molecules with a chemical diversity derived from primary (such as polypeptides, enzymes, and polysaccharides) or secondary (including terpenes, alkaloids and sterols) metabolisms, with a variety of pharmacological and ecological functions $[15,16]$. Over $60 \%$ of bioactive compounds are from marine fauna of which $70 \%$ come from sponges [17-20]. Sponges (phylum Porifera) are the most primitive of multicellular animals. They have existed for 700-800 million years occurring primarily in marine environments at different depths [21]. There are about 8000 species of sponges described which are divided into three groups: Calcarea (five orders, 24 families), Demospongiae (15 orders, 92 families), and Hexactinellida (six orders, 20 families), however, their true diversity may be higher [22,23]. Products isolated from sponges display antiviral [24], anticancer [25], and antimicrobial [26], effects on platelet aggregation [27] and on endothelial cells [28,29]. Some of these products resulted in the synthesis of Ara-A (anticancer) and Ara-C (antiviral) drugs, which were further approved for clinical use [30-32], although their marketing proved to be too expensive. Therefore, bioprospecting in sponges is potentially important for discovering new molecules with antivenom properties in this highly diverse group of animals. 
In the present study, the effect has been evaluated of ten Brazilian marine sponge species (A. viridis, A. fulva, C. collectrix, D. anchorata, D. etheria, H. heliophila, M. angulosa, P. citrina, P. janeirensis, T. ignis) against in vivo (hemorrhage, edema, and lethality) and in vitro (hemolysis, proteolysis, and clotting) activities induced by B. jararaca and L. muta snake venom.

\section{Results}

\subsection{Neutralization of Proteolysis}

$B$. jararaca and L. muta venoms hydrolyzed azocasein in a concentration-dependent manner with one $\mathrm{EC}$ of $17 \mu \mathrm{g} / \mathrm{mL}$ and $16 \mu \mathrm{g} / \mathrm{mL}$, respectively (data not shown). As shown in Figure 1, the sponge extracts $(132 \mu \mathrm{g} / \mathrm{mL})$ inhibited proteolysis induced by two EC of B. jararaca and L. muta venom with different potencies. As observed in the Figure 1A, at 1:8 $(w / w)$ venom:sponge ratio, M. angulosa (column 1), T. ignis (column 3), A. fulva (column 4), D. etheria (column 5), D. anchorata (column 6), $P$. citrina (column 8), and P. janeirensis (column 9) inhibited $100 \%$ of proteolytic activity of B. jararaca venom, while Chondrosia sp. (column 2) and A. viridis (column 7) inhibited around $70 \%-80 \%$. According to Figure 1B, at 1:8 (w/w) venom:sponge ratio, the maximum inhibition against L. muta venom was $80 \%$, achieved by $D$. etheria. The sponge $H$. heliophila did not inhibit proteolytic activity induced by both venoms.

Figure 1. Effect of sponges' extracts on proteolysis induced by B. jararaca or L. muta venom. Marine sponges $(132 \mu \mathrm{g} / \mathrm{mL})$ were incubated for $30 \mathrm{~min}$ at room temperature with $34 \mu \mathrm{g} / \mathrm{mL}$ B. jararaca (Panel A) or with $32 \mu \mathrm{g} / \mathrm{mL}$ L. muta (Panel B), and then proteolysis test performed. M. angulosa (column 1), C. collectrix (column 2), T. ignis (column 3), A. fulva (column 4), D. etheria (column 5), D. anchorata (column 6), A. viridis (column 7), P. citrina (column 8), P. janeirensis (column 9), H. heliophila (column 10). Data are means \pm SE of two individual experiments $(n=3)$.
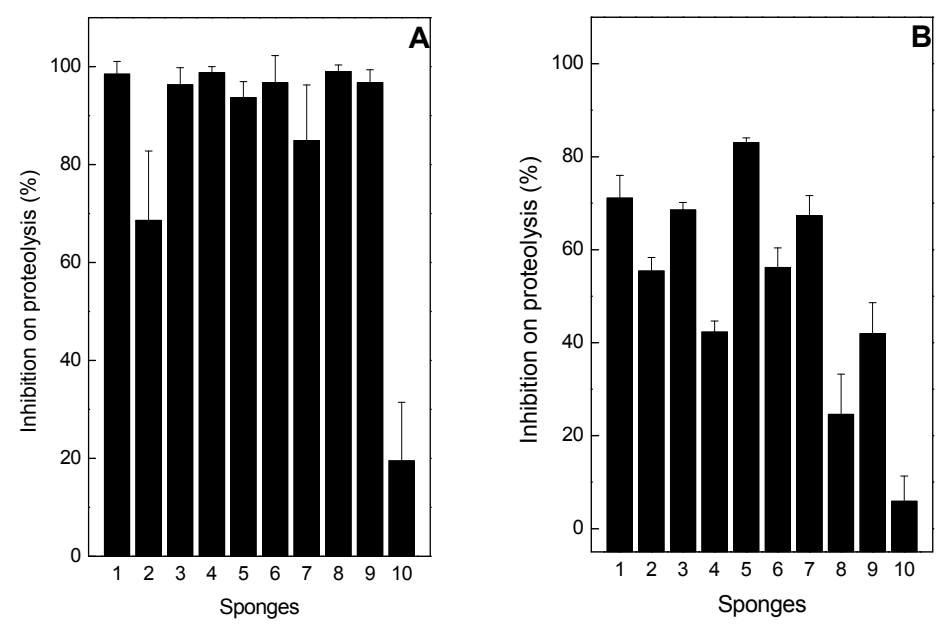

\subsection{Neutralization of Hemorrhage}

The effect of the sponge extracts on hemorrhagic activity of B. jararaca and L. muta venom was evaluated (Figure 2). Intradermal injection of $20 \mu \mathrm{g} / \mathrm{g}$ B. jararaca or $10 \mu \mathrm{g} / \mathrm{g} \mathrm{L}$. muta venom induced a 
hemorrhage halo in mice of $10 \mathrm{~mm}$, which corresponds to one MHD. As shown in Figure 2A, M. angulosa (column 1), D. etheria (column 5), D. anchorata (column 6), and P. citrina (column 8), at a concentration of $220 \mu \mathrm{g} / \mathrm{g}$ (1:11 venom:sponge ratio, $w / w)$, fully protected mice from hemorrhage caused by B. jararaca venom. However, when Chondrosia sp. (column 2), A. fulva (column 4), D. etheria (column 7) were incubated with $B$. jararaca venom, no protection was seen. The extracts of T. ignis (column 3) and $H$. heliophila (column 10) inhibited hemorrhage induced by $B$. jararaca around $40 \%$ and $20 \%$, respectively (Figure $2 \mathrm{~A}$ ). In contrast, the extracts of sponges were not able to inhibit hemorrhage induced by L. muta venom (Figure 2B). Moreover, the sponge extracts (M. angulosa, D. anchorata, P. citrine, and T. ignis), at two concentrations (110 and $220 \mu \mathrm{g} / \mathrm{g}$ ) were injected i.d. $15 \mathrm{~min}$ after $B$. jararaca venom $(20 \mu \mathrm{g} / \mathrm{g})$. In addition, at lower concentration, only the sponges $M$. angulosa and D. anchorata inhibited $20 \%$ and $40 \%$ the hemorrhagic activity of B. jararaca venom, respectively. However, at $220 \mu \mathrm{g} / \mathrm{g}$, P. citrine (35\%) and T. ignis (45\%) inhibited $B$-jararaca-induced hemorrhage as well, and the percentage of inhibition of $M$. angulosa doubled (Figure 2C). In another injection protocol, B. jararaca venom $(20 \mu \mathrm{g} / \mathrm{g})$ was injected i.d. into mice, and the sponge extracts $(220 \mu \mathrm{g} / \mathrm{g})$ were administered intravenously $15 \mathrm{~min}$ later. Now, all the extracts inhibited hemorrhage, but with different profiles: M. angulosa (6\%), D. anchorata (22\%), P. citrine (22\%) and T. ignis (20\%) (Figure 2C).

Figure 2. Effect of the sponge extracts on hemorrhage induced by B. jararaca or L. muta venom. The sponge extracts $(220 \mu \mathrm{g} / \mathrm{g})$ were incubated for $30 \mathrm{~min}$. at room temperature with $20 \mu \mathrm{g} / \mathrm{g} \mathrm{B}$. jararaca (Panel A) or with $10 \mu \mathrm{g} / \mathrm{g} \mathrm{L}$. muta venom (Panel B), then the mixtures were injected into mice and the hemorrhage test results evaluated, as described in the methods. Columns are: Venom with DMSO (Column C), M. angulosa (column 1), C. collectrix (column 2), T. ignis (column 3), A. fulva (column 4), D. etheria (column 5), D. anchorata (column 6), A. viridis (column 7), P. citrina (column 8), P. janeirensis (column 9), H. heliophila (column 10). Data are expressed as means SEM of two individual experiments $(n=3)$. Panel C: B. jararaca venom $(20 \mu \mathrm{g} / \mathrm{g})$ was injected i.d., and $15 \mathrm{~min}$. later, the sponge extracts M. angulosa $(\mathrm{Ma})$, D. anchorata $(\mathrm{Da})$, P. citrine $(\mathrm{Pc})$ and T. ignis (Ti), $110 \mu \mathrm{g} / \mathrm{g}$ (black columns) or $220 \mu \mathrm{g} / \mathrm{g}$ (white columns) were injected i.d. or i.v. $(220 \mu \mathrm{g} / \mathrm{g}$, hatched columns). * Significance level $(p<0.05)$ when compared to columns $\mathrm{C}$.
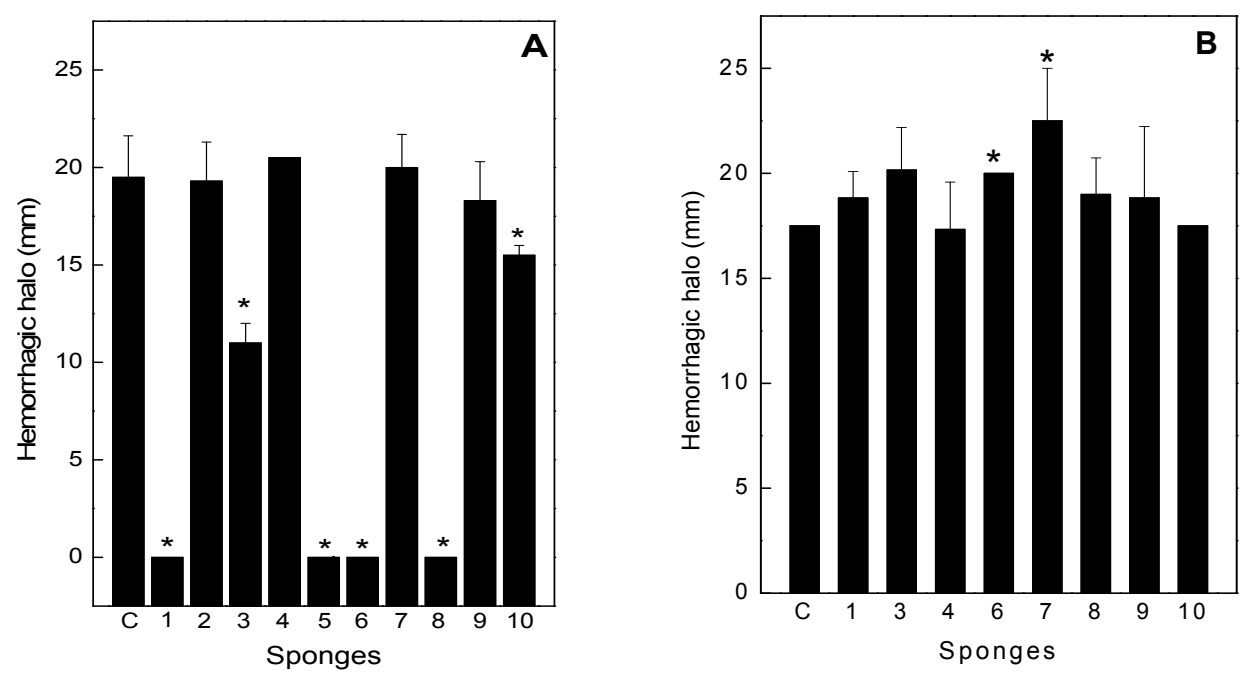
Figure 2. Cont.

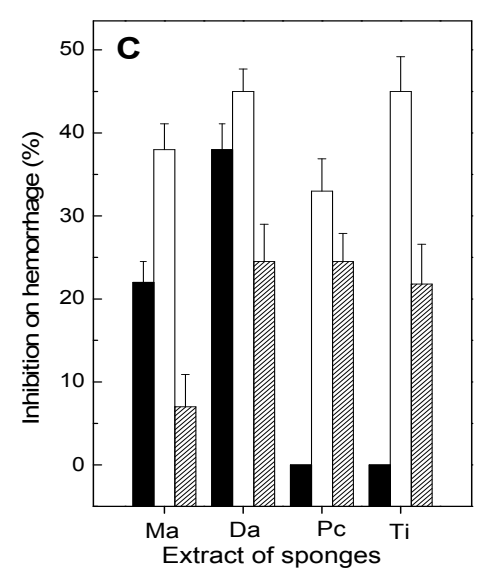

\subsection{Neutralization of Hemolysis}

As shown in Figure 3A, most of the sponge extracts, at 1:2 venom:sponge ratio $(w / w)$ inhibited hemolysis induced by $B$. jararaca from $0 \%$ to $20 \%$, with the exception of $P$. citrina sponge, that inhibited $90 \%$ of hemolysis. Similar results were obtained with $P$. citrina for inhibition of L. muta-induced hemolysis (Figure 3B). However, most of the other sponges inhibited over $20 \%$ of hemolysis induced by L. muta venom (Figure 3B). The extracts of A. fulva (column 4), D. etheria (column 5) did not inhibit hemolysis induced by B. jararaca (Figure 3A) and H. heliophila (column 10) did not inhibit hemolysis induced by L. muta (Figure 3B).

Figure 3. Effect of the sponge extracts on hemolysis induced by B. jararaca or L. muta venom. For Panel A, the sponge extracts $(100 \mu \mathrm{g} / \mathrm{mL})$ were incubated with $50 \mu \mathrm{g} / \mathrm{mL}$ B. jararaca and for Panel B, sponges $(50 \mu \mathrm{g} / \mathrm{mL})$ were incubated with $25 \mu \mathrm{g} / \mathrm{mL} \mathrm{L}$. muta, then hemolytic tests were performed. Columns are: Venoms incubated with $M$. angulosa (column 1), or with C. collectrix (column 2), or with T. ignis (column 3), or with A. fulva (column 4), or with D. etheria (column 5), or with D. anchorata (column 6), or with A. viridis (column 7), or with P. citrina (column 8), or with P. janeirensis (column 9), or with H. heliophila (column 10). Data are expressed as means SEM of three individual experiments $(n=3)$.
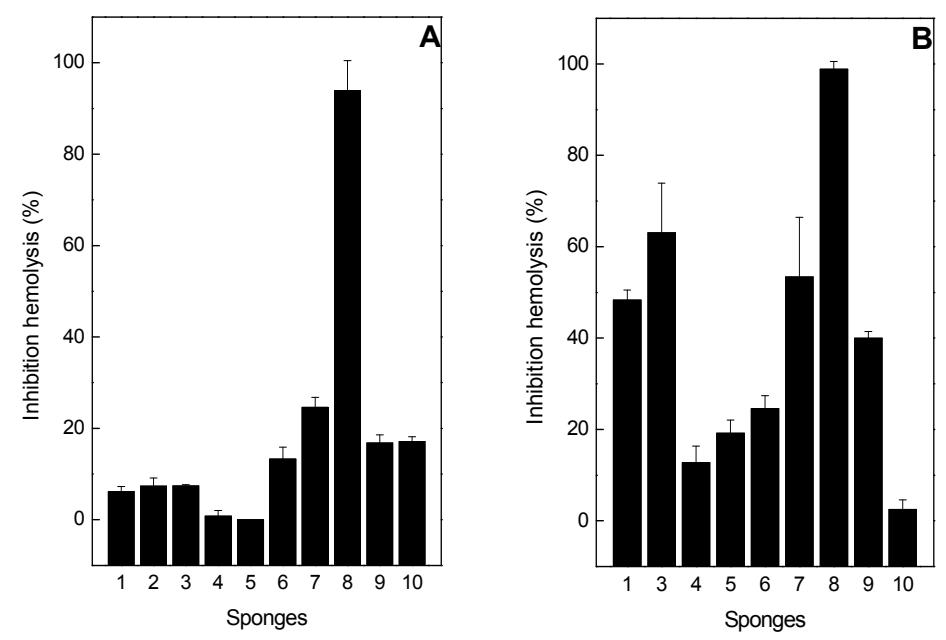


\subsection{Neutralization of coagulation}

B. jararaca $(50 \mu \mathrm{g} / \mathrm{mL})$ and L. muta $(10 \mu \mathrm{g} / \mathrm{mL})$ venom clotted plasma after $c a .60 \mathrm{~s}$ and this was designated one MCD. When the venoms at $1 \mathrm{MCD}$ were incubated with the sponge extracts, only inhibition of B. jararaca-induced clotting was observed (Figure 4A). Most sponges doubled the clotting time, when compared with the control value. However, P. citrina delayed clotting time approximately three times (Figure 4A, column 8). H. heliophila did not inhibit clotting induced by B. jararaca venom (Figure 4A, column 11). All sponge extracts failed to inhibit clotting induced by L. muta venom (Figure 4B). None of the sponge extracts induced clotting.

Figure 4. Effect of the sponge extracts on coagulation induced by B. jararaca or L. muta. B. jararaca (Panel A) or L. muta (Panel B) venoms were incubated with $0.5 \%$ DMSO (column 0), M. angulosa (column 1), C. collectrix (column 2), T. ignis (column 3), A. fulva (column 4), D. etheria (column 5), D. anchorata (column 6), A. viridis (column 7), P. citrina (column 8), P. janeirensis (column 9), H. heliophila (column 10), for $30 \mathrm{~min}$ at room temperature. After the mixture was added to the plasma, the clotting time was recorded, as described in the Methods. Data are expressed as means SEM of three individual experiments $(n=3)$. * Significance level $(p<0.05)$ when compared to column 0 .
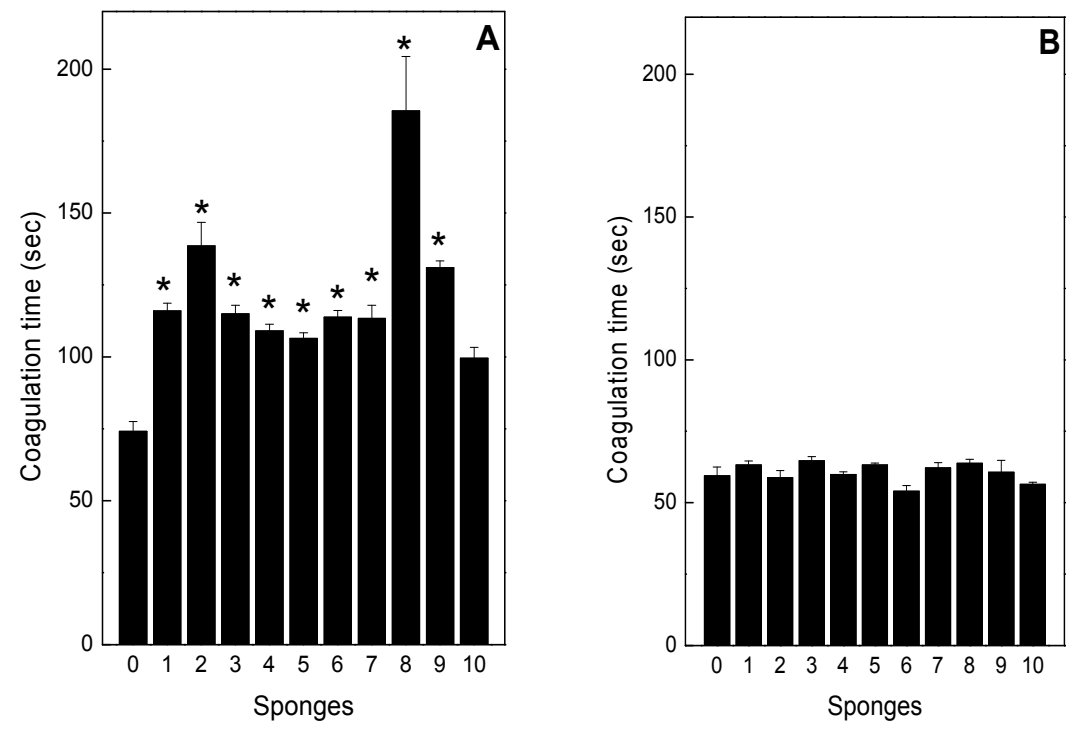

\subsection{Neutralization of Edema and Lethality}

A sub-plantar injection of B. jararaca $(0.7 \mu \mathrm{g} / \mathrm{g})$ or $L$. muta $(0.4 \mu \mathrm{g} / \mathrm{g})$ venom into the paws of mice induced an increase in paw volume of $26 \%$ and $44 \%$, respectively. Subsequently, the sponge extracts were incubated with the venoms to give a final venom:ratio $(w / w)$ of 1:14 for B. jararaca or 1:12 for L. muta, and the mixtures were injected into mice and edemas evaluated. None of the sponge extracts inhibited edema induced by B. jararaca venom, but different percentages of inhibition occurred for L. muta-induced edema (Figure 5). T. ignis (column 2) inhibited 20\%, while A. fulva (column 3), D. anchorata (column 4), and H. heliophila (column 8), inhibited around $40 \%$ edema. When injected separately, the extracts did not induce edema in mice. 
Figure 5. Effect of the sponge extracts on the edematogenic activity induced by L. muta venom. L. muta $(0.4 \mu \mathrm{g} / \mathrm{g})$ venom was incubated for $30 \mathrm{~min}$ at room temperature with $4.8 \mu \mathrm{g} / \mathrm{g}$ sponge extracts: M. angulosa (column 1), T. ignis (column 2), A. fulva (column 3), D. anchorata (column 4), A. viridis (column 5), P. citrina (column 6), P. janeirensis (column 7), or H. heliophila (column 8). Data are expressed as means SEM of three individual experiments $(n=3)$.

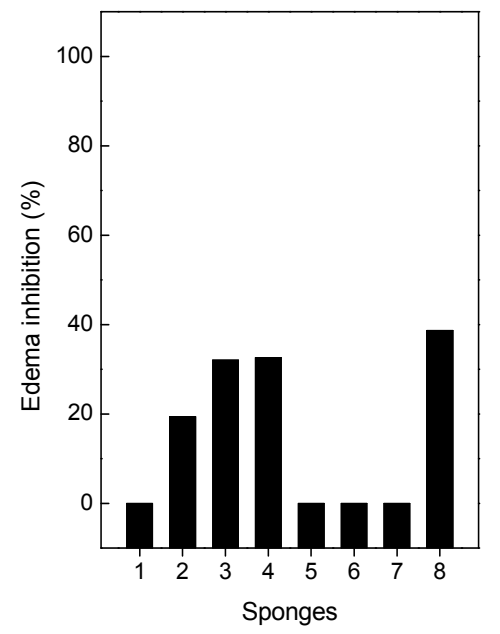

When $B$. jararaca venom $(60 \mu \mathrm{g} / \mathrm{g})$ was injected i.p. into mice, $100 \%$ lethality occurred after $126 \mathrm{~min}$. (Table 1). The sponge extracts $(12 \mu \mathrm{g} / \mathrm{g})$ were incubated with $B$. jararaca venom to give a 1:2 venom:sponge ratio $(w / w)$, and then mixtures were injected i.p. into mice. As shown in Table 1, $100 \%$ survival rates were observed for A. fulva, A. viridis, and P. citrina extracts up to 126 min. observation, with deaths only occurring at 258, 258, and $372 \mathrm{~min}$, respectively. In contrast, the other sponge extracts protected the mice to a lesser extent. As only the sponge extracts of $A$. fulva, $A$. viridis, and $P$. citrine protected mice from death, another protocol of injection was done. The sponge extracts were injected either i.p. or i.v. 15 min after injection i.p. of B. jararaca venom. When sponges were injected i.p., no protection in mice was observed. However, a slight protection was seen for A. fulva when injection was performed i.v., in which mice that received only the venom died around $96 \mathrm{~min}$ and those treated with A. fulva died around $128 \mathrm{~min}$ (data not shown). None of the sponge extracts $(500 \mu \mathrm{g} / \mathrm{g})$ were lethal when injected i.p. into mice.

Table 1. Antilethality activity of the sponge extracts against $B$. jararaca venom.

\begin{tabular}{cc}
\hline Groups & Survival time (min) \\
\hline B. jararaca $+\mathrm{NaCl}$ & $126 \pm 0.5$ \\
B. jararaca $+\mathrm{DMSO}$ & $108 \pm 0.9$ \\
B. jararaca + M. angulosa & $150 \pm 0$ \\
B. jararaca + T. ignis & $180 \pm 0$ \\
B. jararaca + A. fulva & $258 \pm 3.2$ \\
B. jararaca + D. anchorata & $150 \pm 0$ \\
B. jararaca + A. viridis & $258 \pm 3.2$ \\
B. jararaca + P. citrine & $372 \pm 3.2$ \\
B. jararaca $+P$. janeirensis & $150 \pm 0$ \\
B. jararaca + H. heliophila & $168 \pm 0.5$ \\
\hline
\end{tabular}




\section{Discussion}

In the present paper, it has been shown, for the first time, that extracts of marine sponges inhibit in vivo (hemorrhagic, edema and lethality) and in vitro (clotting, proteolytic and hemolytic) biological effects induced by snake venoms from B. jararaca and L. muta. However, the mechanism of inhibitory action of the sponges is not yet understood. Significant effects of B. jararaca and L. muta venoms, following snakebites have been reported previously [9,33]. Antivenom therapy not only fails to efficiently neutralize the local effects of envenomation, but also presents problems in its use [34,35]. The search for alternative treatments has therefore been intense and molecules from natural sources have been extensively prospected to result in discoveries such as a diterpene from the alga Canistrocarpus cervicornis [36]. However, to date, no effective bioproducts have been marketed as effective medicines for the treatment of envenomation by snakes. The plant kingdom has provided alternatives to antivenom therapy in the form of folk medicines to inhibit the symptoms of envenomation but such preparations are not widely accepted for use by the medical profession [37,38]. Very few previous reports have studied the potential of sponges in the treatment of envenomation [39-41].

Our results showed that sponge extracts inhibited the biological effects induced by B.jararaca and L. muta venoms, but with different potencies. These effects result from the action of proteases (serine and metalloproteases), which interfere with the blood-clotting cascade and blood vessels, which may lead to hemorrhage $[3,4]$. These enzymes in venoms are directly involved in the local effects that are responsible for amputations and deformities in victims as well as in the systemic symptoms. The injection of B. jararaca venom was lethal to mice after $c a$. two hours and only extracts of the sponges, A. fulva, A. viridis, or $P$. citrine, increased the survival rates of these mice. Other results with the sponge extracts were also promising, as both local and systemic actions of the venoms were also inhibited. The sponge extract inhibited hemolysis induced by the venoms and possibly this was due to a structural modification of phospholipase $\mathrm{A}_{2}\left(\mathrm{PLA}_{2}\right)$ enzymes or resulted from chelation of $\mathrm{Ca}^{2+}$ ions. $\mathrm{PLA}_{2} \mathrm{~S}$ are another class of enzymes abundant in snake venoms with a vast variety of pathophysiological functions. These functions include erythrocyte lysis through a calcium-dependent reaction, myotoxicity, edema, hemorrhage, lethality, and effects on platelet aggregation $[42,43]$. Manoalide, a nonsteroidal sesterterpenoid isolated from the sponge Luffariella variabilis has already been shown to inhibit a cobra PLA 2 by interacting with lysine residues in the enzyme [40].

Envenomation usually leads to intense inflammatory and edema reactions and $\mathrm{PLA}_{2}$ enzymes also participate together with other enzymes in these responses. Our results showed that the sponge extracts inhibited edema induced by L. muta, but not that resulting from B. jararaca. Extracts of M. angulosa, D. etheria, D. anchorata, and P. citrina inhibited L. muta-induced local hemorrhage, but not that caused by B. jararaca. Again, inhibition of edematogenic or hemorrhagic activity may have occurred by chelating divalent metals, such as $\mathrm{Ca}^{2+}$ or $\mathrm{Zn}^{2+}$, that are co-factors for enzymes involved both effects [39]. Despite similar composition of the B. jararaca and L. muta venoms, there are different isoforms that may explain the differences in the inhibitory profiles by the sponges. Analysis of phylogenetic trees shows that during evolutionary processes, some toxins lost or changed their activity and/or some key amino acid residues in the primary structure were replaced by others. This fact may lead to a diversity of physiological activities [44-46]. Among all the sponges tested, P. citrina inhibited all the biological activities induced by L. muta or B. jararaca venoms. Bastos et al. [47] have 
reported antiviral activity of $P$. citrina, but in fact its antiviral effect is due to the presence of symbiotic microorganisms. Most of sponges live in symbiosis with a diversity of microorganisms, representing more than $35 \%$ of the total body mass and they impart some of the biological functions to sponges, such as nutrition, defense and pharmacological properties $[48,49]$. However, some of the sponge bioactivities are due to the secondary metabolites synthesized during the sponge metabolism [50]. Finally, the different inhibitory profiles recorded by the sponge extracts against the effects of B. jararaca or L. muta venoms may have resulted from variations in the symbiotic microbial communities in the sponges.

\section{Experimental Section}

\subsection{Venom and Animals}

Bothrops jararaca and Lachesis muta snake venom were kindly supplied from the Fundação Ezequiel Dias (FUNED), Belo Horizonte, Minas Gerais state, Brazil, vacuum dried and stored at $-20{ }^{\circ} \mathrm{C}$ until use. Balb/c mice $(18-20 \mathrm{~g})$ were obtained from the Núcleo de Animais de Laboratório (NAL) of the Universidade Federal Fluminense (UFF). They were housed under constant temperature $\left(24 \pm 1{ }^{\circ} \mathrm{C}\right)$ and light conditions. Experiments performed were approved by the UFF Institutional Committee for Ethics in Animal Experimentation (number 25) and were in accordance with the guidelines of the Brazilian Committee for Animal Experimentation (COBEA).

\subsection{Marine Sponge Extracts}

Specimens of marine sponges M. angulosa, C. collectrix, T. ignis, A. fulva, D. anchorata, D. etheria, A. viridis, P. janeirensis, H. heliophila, P. citrina were collected by free or scuba diving, extracted twice with acetone at room temperature $\left(25^{\circ} \mathrm{C}\right)$ for $24 \mathrm{~h}$. Then, sponges were extracted for $72 \mathrm{~h}$ under the same conditions, filtered, and the solvent was evaporated off under reduced pressure, yielding a crude residue. An aliquot of each extract was weighed, aliquoted and frozen at $-20{ }^{\circ} \mathrm{C}$. The extracts of sponges were then dissolved in dimethyl sulfoxide (DMSO) to perform the biological assays. Voucher specimen of each sponge has been deposited at Museu Nacional of the Universidade Federal do Rio de Janeiro (MN/UFRJ), RJ, Brazil and authenticated by Dr. Guilherme Muricy and Dr. Suzi Ribeiro of the MN/UFRJ. The experimental procedures employed remove sugar and proteins, and extract less polar components and nonpolar ones, as diterpenes, alkaloids, fatty acids, and sterols.

\subsection{Antiproteolytic Activity}

Proteolytic activity of B. jararaca and L. muta venom was determined using azocasein as the substrate $\left(0.2 \% w / v\right.$, in $20 \mathrm{mM}$ Tris- $\left.\mathrm{HCl}, 8 \mathrm{mM} \mathrm{CaCl}_{2}, \mathrm{pH} 8.8\right)$, with minor modifications [51]. An Effective Concentration (EC) was defined as the amount of venom $(\mu \mathrm{g} / \mathrm{mL})$ able to produce a variation of about 0.2 OD units at A 420. The inhibitory effect of sponges was performed by incubating them with two EC of B. jararaca and L. muta venom for $30 \mathrm{~min}$ at room temperature and then, proteolysis was measured. Control experiments were conducted by mixing venom with DMSO or saline and any proteolysis was recorded. 


\subsection{Antihemorrhagic Activity}

Hemorrhagic lesions produced by B. jararaca and L. muta venom were quantified using a procedure described by Kondo [52], with minor modifications. Briefly, samples (100 $\mu \mathrm{L})$ were injected intradermally (i.d.) into abdominal skin of mice. Two hours later, the animals were euthanized, abdominal skin removed, stretched, and inspected for visual changes in the internal aspect in order to localize hemorrhagic spots. Hemorrhage was quantified as the Minimum Hemorrhagic Dose (MHD), defined as the amount of venom $(\mathrm{mg} / \mathrm{kg})$ able to produce a hemorrhagic halo of $10 \mathrm{~mm}$. The inhibitory effect of sponge extracts was investigated using three different protocols: (1) incubation samples with one MHD of B. jararaca and L. muta venom for $30 \mathrm{~min}$ at room temperature and then, the mixture $(100 \mu \mathrm{L})$ was injected into mice and the hemorrhage was measured. For the other two protocols, one MHD of $B$. jararaca venom was injected i.d., and 15 min later, (2) the sponge extracts were injected i.d. at the same site where venom had been administered or 3) they were injected i.v. Hemorrhagic activity was expressed as the mean diameter (in millimeters) of the hemorrhagic halo induced by $B$. jararaca and L. muta venom in the absence and presence of the sponges. Negative control experiments were performed by injecting DMSO or saline.

\subsection{Antihemolytic Activity}

The degree of hemolysis of B. jararaca and L. muta venom was determined by the indirect hemolytic test using human erythrocytes and hen's egg yolk emulsion as substrates [53]. The amount of B. jararaca and L. muta venom ( $\mu \mathrm{g} / \mathrm{mL})$ that produced $100 \%$ hemolysis was denoted as Minimum Indirect Hemolytic Dose (MIHD). Inhibitory experiments were performed by incubating sponge extracts with one MIHD for $30 \mathrm{~min}$ at room temperature, and then hemolytic activity was evaluated. Control experiments were performed by incubating venom with DMSO or saline, instead of sponges.

\subsection{Anticlotting Activity}

The clotting activity of B. jararaca and L. muta venom was determined on an Amelung coagulometer, model KC4A (Labcon, Germany). Different concentrations of both venoms were mixed with a pool of human citrated plasma diluted in saline (1:1) from healthy volunteers from the local blood bank (Hospital Universitário Antônio Pedro-HUAP, Universidade Federal Fluminense). The amount of venom $(\mu \mathrm{g} / \mathrm{mL})$ that clots plasma in 60 seconds was denoted as the Minimum Coagulant Dose (MCD). To evaluate the inhibitory effect, sponge extracts were preincubated for 30 min at room temperature with one MCD of venom, and then, the mixture was added to plasma and clotting time recorded. Control experiments were performed in parallel by adding DMSO or saline preincubated with venom, instead of sponge extracts.

\subsection{Antiedematogenic Activity}

Edema-inducing activity of B. jararaca $(0.7 \mu \mathrm{g} / \mathrm{g})$ or L. muta $(0.4 \mu \mathrm{g} / \mathrm{g})$ venom was determined according to [54], with minor modification. Groups of five mice received subcutaneously (s.c.) $50 \mu \mathrm{L}$ of $B$. jararaca venom $(7 \mathrm{mg} / \mathrm{kg})$ or L. muta $(7 \mathrm{mg} / \mathrm{kg})$ in the right paw, while the left paw received $50 \mu \mathrm{L}$ of saline or DMSO. One hour after injection, edema was evaluated as the percentage increase in 
weight of the right paw compared to the left one. Antiedematogenic activity was performed by incubating the extracts of sponges $(140 \mathrm{mg} / \mathrm{kg})$ with B. jararaca or L. muta venom for $30 \mathrm{~min}$ at room temperature, and then mixture was injected into mice. Control experiments were performed by incubating venoms with DMSO or saline.

\subsection{Antilethality Activity}

Groups of five mice received injection intraperitoneally (i.p.) of $B$. jararaca venom $(6 \mu \mathrm{g} / \mathrm{g})$. The antilethality experiment was performed by mixing $B$. jararaca venom with the extracts of sponges $(14 \mu \mathrm{g} / \mathrm{g})$ for $30 \mathrm{~min}$ at $37^{\circ} \mathrm{C}$, and then mixtures was injected i.p. into mice. Also, B. jararaca venom was injected i.p into mice, and 15 min later, the sponge extracts were injected i.p. or i.v. Control experiments were performed by incubating venom with DMSO $(1 \%, v / v$, final concentration) or with saline. The volume of the injection was $0.1 \mathrm{~mL}$, and after injection, the number of dead mice was counted in each group.

\subsection{Statistical Analysis}

Results are expressed as means \pm SEM obtained with the indicated number of animals or experiments performed. The statistical significance of differences among experimental groups was evaluated using the Student's $t$ test and $p$ values of $\leq 0.05$ were considered statistically significant.

\section{Conclusion}

This research demonstrated that marine sponges are undoubtedly rich sources of biologically active-molecules with antivenom potential able to inhibit the main toxic effects of $L$. muta and B. jararaca. Substances derived from sponges could be used as antivenom preparations or as aids to complement other treatments of snakebites. This study also highlights bioprospecting approaches, aimed to explore the rich flora and fauna in the Brazilian oceans in order to enhance the discovery of new antivenom molecules. However, in-depth scientific investigations are imperative to evaluate the antivenom potential of natural products in order to derive therapeutically effective treatments for snakebites. It should be emphasized that experimental models for in vivo and in vitro studies should be developed to closely reflect the clinical situations of snakebites.

\section{Acknowledgments}

This work was supported by International Foundation for Science (F/4571-1) and by Brazilian funding agencies: CPNq, FAPERJ, CAPES and UFF/PROPPi. We would like to thank Olga Maria Diniz Pereira (UFF) for providing the blood bags and Norman Ratcliffe, from Swansea University, United Kingdom for kindly revising the manuscript.

\section{Conflicts of interest}

The authors declare no conflict of interest. 


\section{References}

1. Chippaux, J.P. Snake-bites: Appraisal of the global situation. Bull. World Health Organ. 1998, 76, 515-524.

2. Kasturiratne, A.; Wickremasinghe, A.R.; De Silva, N.; Gunawardena, N.K.; Pathmeswaran, A.; Premaratna, R.; Savioli, L.; Lalloo, D.G.; De Silva, H.J. The global burden of snakebite: A literature analysis and modelling based on regional estimates of envenoming and deaths. PLoS Med. 2008, 5, e218.

3. Baldo, C.; Jamora, C.; Yamanouye, N.; Zorn, T.M.; Moura-da-Silva, A.M. Mechanisms of vascular damage by hemorrhagic snake venom metalloproteinases: Tissue distribution and in situ hydrolysis. PLoS Negl. Trop. Dis. 2010, 4, e727.

4. Braud, S.; Bon, C.; Wisner, A. Snake venom proteins acting on hemostasis. Biochimie 2000, 82, 851-859.

5. Pidde-Queiroz, G.; Furtado Mde, F.; Filgueiras, C.F.; Pessoa, L.A.; Spadafora-Ferreira, M.; Van den Berg, C.W.; Tambourgi, D.V. Human complement activation and anaphylatoxins generation induced by snake venom toxins from Bothrops genus. Mol. Immunol. 2010, 47, 2537-2544.

6. Barone, J.M.; Alponti, R.F.; Frezzatti, R.; Zambotti-Villela, L.; Silveira, P.F. Differential efficiency of simvastatin and lipoic acid treatments on Bothrops jararaca envenomation-induced acute kidney injury in mice. Toxicon 2011, 57, 148-156.

7. Rucavado, A.; Flores-Sanchez, E.; Franceschi, A.; Magalhaes, A.; Gutierrez, J.M. Characterization of the local tissue damage induced by LHF-II, a metalloproteinase with weak hemorrhagic activity isolated from Lachesis muta muta snake venom. Toxicon 1999, 37, 1297-1312.

8. Teixeira Cde, F.; Fernandes, C.M.; Zuliani, J.P.; Zamuner, S.F. Inflammatory effects of snake venom metalloproteinases. Mem. Inst. Oswaldo Cruz 2005, 100, 181-184.

9. MS (Ministério da Saúde)/FUNASA (Fundação Nacional da Saúde). Manual de Diagnóstico e Tratamento de Acidentes por Animais Peçonhentos; MS/ FUNASA: Brasilia, Brazil, 2001.

10. Cardoso, J.L.C.; França, F.O.S.; Fan, H.W.; Malaque, C.M.S.; Haddad, V., Jr. Animais Peçonhentos no Brasil. Biologia, Clínica e Terapêutica dos Acidentes; Sarvier/Fapesp: São Paulo, Brazil, 2003; p. 469.

11. Gutierrez, J.M.; Leon, G.; Burnouf, T. Antivenoms for the treatment of snakebite envenomings: The road ahead. Biologicals 2011, 39, 129-142.

12. Theakston, R.D.; Fan, H.W.; Warrell, D.A.; Da Silva, W.D.; Ward, S.A.; Higashi, H.G. Use of enzyme immunoassays to compare the effect and assess the dosage regimens of three Brazilian Bothrops antivenoms. The Butantan Institute Antivenom Study Group (BIASG). Am. J. Trop. Med. Hyg. 1992, 47, 593-604.

13. Isbister, G.K.; White, J.; Currie, B.J.; O’Leary, M.A.; Brown, S.G.; Investigators, A.S.P. Clinical effects and treatment of envenoming by Hoplocephalus spp. snakes in Australia: Australian Snakebite Project (ASP-12). Toxicon 2011, 58, 634-640. 
14. De Silva, H.A.; Pathmeswaran, A.; Ranasinha, C.D.; Jayamanne, S.; Samarakoon, S.B.; Hittharage, A.; Kalupahana, R.; Ratnatilaka, G.A.; Uluwatthage, W.; Aronson, J.K.; et al. Low-dose adrenaline, promethazine, and hydrocortisone in the prevention of acute adverse reactions to antivenom following snakebite: A randomised, double-blind, placebo-controlled trial. PLoS Med. 2011, 8, e1000435.

15. Aneiros, A.; Garateix, A. Bioactive peptides from marine sources: Pharmacological properties and isolation procedures. J. Chromatogr. B 2004, 803, 41-53.

16. Blunt, J.W.; Copp, B.R.; Keyzers, R.A.; Munro, M.H.; Prinsep, M.R. Marine natural products. Nat. Prod. Rep. 2013, 30, 237-323.

17. Kijjoa, A.; Sawangwong, P. Drugs and Cosmetics from the Sea. Mar. Drugs 2004, 2, 73-82.

18. Sipkema, D.; Franssen, M.C.; Osinga, R.; Tramper, J.; Wijffels, R.H. Marine sponges as pharmacy. Mar. Biotechnol. 2005, 7, 142-162.

19. Mayer, A.M.; Hamann, M.T. Marine pharmacology in 2001-2002: Marine compounds with anthelmintic, antibacterial, anticoagulant, antidiabetic, antifungal, anti-inflammatory, antimalarial, antiplatelet, antiprotozoal, antituberculosis, and antiviral activities; affecting the cardiovascular, immune and nervous systems and other miscellaneous mechanisms of action. Comp. Biochem. Physiol. C 2005, 140, 265-286.

20. Ohno, O.; Suenaga, K.; Uemura, D. Secondary metabolites with new medicinal functions from marine organisms. Adv. Food Nutr. Res.2012, 65, 185-193.

21. Newman, D.J.; Cragg, G.M. Marine natural products and related compounds in clinical and advanced preclinical trials. J. Nat. Prod. 2004, 67, 1216-1238.

22. Cardenas, P.; Perez, T.; Boury-Esnault, N. Sponge systematics facing new challenges. Adv. Mar. Biol. 2012, 61, 79-209.

23. Worheide, G.; Dohrmann, M.; Erpenbeck, D.; Larroux, C.; Maldonado, M.; Voigt, O.; Borchiellini, C.; Lavrov, D.V. Deep phylogeny and evolution of sponges (phylum Porifera). Adv. Mar. Biol. 2012, 61, 1-78.

24. Yasuhara-Bell, J.; Lu, Y. Marine compounds and their antiviral activities. Antiviral Res. 2010, 86, 231-240.

25. Xu, J.; Hasegawa, M.; Harada, K.; Kobayashi, H.; Nagai, H.; Namikoshi, M. Melophlins P, Q, R, and S: Four new tetramic acid derivatives, from two Palauan marine sponges of the genus Melophlus. Chem. Pharm. Bull. 2006, 54, 852-854.

26. Wright, A.D.; McCluskey, A.; Robertson, M.J.; MacGregor, K.A.; Gordon, C.P.; Guenther, J. Anti-malarial, anti-algal, anti-tubercular, anti-bacterial, anti-photosynthetic, and anti-fouling activity of diterpene and diterpene isonitriles from the tropical marine sponge Cymbastela Hooperi. Org. Biomol. Chem. 2011, 9, 400-407.

27. De Andrade Moura, L.; Ortiz-Ramirez, F.; Cavalcanti, D.N.; Ribeiro, S.M.; Muricy, G.; Teixeira, V.L.; Fuly, A.L. Evaluation of marine brown algae and sponges from Brazil as anticoagulant and antiplatelet products. Mar. Drugs 2011, 9, 1346-1358.

28. Martinez-Poveda, B.; Garcia-Vilas, J.A.; Cardenas, C.; Melgarejo, E.; Quesada, A.R.; Medina, M.A. The brominated compound aeroplysinin-1 inhibits proliferation and the expression of key pro-inflammatory molecules in human endothelial and monocyte cells. PloS One 2013, 8, e55203. 
29. Kim, G.D.; Cheong, O.J.; Bae, S.Y.; Shin, J.; Lee, S.K. 6'-Debromohamacanthin A, a bis (indole) alkaloid, inhibits angiogenesis by targeting the VEGFR2-mediated PI3K/AKT/mTOR signaling pathways. Mar. Drugs 2013, 11, 1087-1103.

30. Bergmann, W.; Feeney, R.J. The isolation of a new thymine pentoside from sponges. J. Am. Chem. Soc. 1950, 72, 2809-2810.

31. Sagar, S.; Kaur, M.; Minneman, K.P. Antiviral lead compounds from marine sponges. Mar. Drugs 2010, 8, 2619-2638.

32. Bergmann, W.; Feeney, R.J. Contribution to the study of marine products. XXXII. The nucleosides of sponges. J. Org. Chem. 1951, 16, 981-987.

33. Fuly, A.L.; Francischetti, I.M.; Zingali, R.B.; Carlini, C.R. Partial purification and some physicochemical properties of phospholipases $\mathrm{A}_{2}$ from the venom of the bushmaster snake (Lachesis muta). Braz. J. Med. Biol. Res. 1993, 26, 459-463.

34. Gupta, Y.K.; Peshin, S.S. Do herbal medicines have potential for managing snake bite envenomation? Toxicol. Int. 2012, 19, 89-99.

35. Williams, D.J.; Jensen, S.D.; Nimorakiotakis, B.; Muller, R.; Winkel, K.D. Antivenom use, premedication and early adverse reactions in the management of snake bites in rural Papua New Guinea. Toxicon 2007, 49, 780-792.

36. De Andrade Moura, L.; Bianco, E.M.; Pereira, R.C.; Teixeira, V.L.; Fuly, A.L. Anticoagulation and antiplatelet effects of a dolastane diterpene isolated from the marine brown alga Canistrocarpus cervicornis. J. Thromb. Thrombolysis 2011, 31, 235-240.

37. Martz, W. Plants with a reputation against snakebite. Toxicon 1992, 30, 1131-1142.

38. Houghton, P.J.; Osibogun, I.M. Flowering plants used against snakebite. J. Ethnopharmacol. 1993, 39, 1-29.

39. Sauleau, P.; Martin, M.T.; Dau, M.E.; Youssef, D.T.; Bourguet-Kondracki, M.L. Hyrtiazepine, an azepino-indole-type alkaloid from the Red Sea marine sponge Hyrtios erectus. J. Nat. Prod. 2006, 69, 1676-1679.

40. Lombardo, D.; Dennis, E.A. Cobra venom phospholipase $\mathrm{A}_{2}$ inhibition by manoalide. A novel type of phospholipase inhibitor. J. Biol. Chem. 1985, 260, 7234-7240.

41. De Freitas, J.C.; Blankemeier, L.A.; Jacobs, R.S. In vitro inactivation of the neurotoxic action of beta-bungarotoxin by the marine natural product, manoalide. Experientia 1984, 40, 864-865.

42. Fujisawa, D.; Yamazaki, Y.; Lomonte, B.; Morita, T. Catalytically inactive phospholipase $\mathrm{A}_{2}$ homologue binds to vascular endothelial growth factor receptor-2 via a $C$-terminal loop region. Biochem. J. 2008, 411, 515-522.

43. De Paula, R.C.; Castro, H.C.; Rodrigues, C.R.; Melo, P.A.; Fuly, A.L. Structural and pharmacological features of phospholipases $\mathrm{A}_{2}$ from snake venoms. Protein Pep. Lett. 2009, 16, 899-907.

44. Fagundes, F.H.; Aparicio, R.; Dos Santos, M.L.; Diz Filho, E.B.; Oliveira, S.C.; Toyama, D.O.; Toyama, M.H. A catalytically inactive Lys49 PLA 2 isoform from Bothrops jararacussu venom that stimulates insulin secretion in pancreatic beta cells. Protein Pep. Lett. 2011, 18, 1133-1139. 
45. Junqueira-de-Azevedo, I.L.; Ching, A.T.; Carvalho, E.; Faria, F.; Nishiyama, M.Y., Jr.; Ho, P.L.; Diniz, M.R. Lachesis muta (Viperidae) cDNAs reveal diverging pit viper molecules and scaffolds typical of cobra (Elapidae) venoms: Implications for snake toxin repertoire evolution. Genetics 2006, 173, 877-889.

46. Serrano, S.M.; Shannon, J.D.; Wang, D.; Camargo, A.C.; Fox, J.W. A multifaceted analysis of viperid snake venoms by two-dimensional gel electrophoresis: An approach to understanding venom proteomics. Proteomics 2005, 5, 501-510.

47. Bastos, J.C.; Kohn, L.K.; Fantinatti-Garboggini, F.; Padilla, M.A.; Flores, E.F.; da Silva, B.P.; De Menezes, C.B.; Arns, C.W. Antiviral activity of Bacillus sp. isolated from the marine sponge Petromica citrina against bovine viral diarrhea virus, a surrogate model of the hepatitis $\mathrm{C}$ virus. Viruses 2013, 5, 1219-1230.

48. Phelan, R.W.; Barret, M.; Cotter, P.D.; O’Connor, P.M.; Chen, R.; Morrissey, J.P.; Dobson, A.D.; O’Gara, F.; Barbosa, T.M. Subtilomycin: A new lantibiotic from Bacillus subtilis strain MMA7 isolated from the marine sponge Haliclona simulans. Mar. Drugs 2013, 11, 1878-1898.

49. Thomas, T.R.; Kavlekar, D.P.; LokaBharathi, P.A. Marine drugs from sponge-microbe association-A review. Mar. Drugs 2010, 8, 1417-1468.

50. Marinho, P.R.; Simas, N.K.; Kuster, R.M.; Duarte, R.S.; Fracalanzza, S.E.; Ferreira, D.F.; Romanos, M.T.; Muricy, G.; Giambiagi-Demarval, M.; Laport, M.S. Antibacterial activity and cytotoxicity analysis of halistanol trisulphate from marine sponge Petromica citrina. J. Antimicrob. Chemother. 2012, 67, 2396-2400.

51. Garcia, E.S.; Guimaraes, J.A.; Prado, J.L. Purification and characterization of a sulfhydryl-dependent protease from Rhodnius prolixus midgut. Arch. Biochem. Biophys. 1978, $188,315-322$.

52. Kondo, H.; Kondo, S.; Ikezawa, H.; Murata, R. Studies on the quantitative method for determination of hemorrhagic activity of Habu snake venom. Jpn. J. Med. Sci. Biol. 1960, 13, 43-52.

53. Fuly, A.L.; De Miranda, A.L.; Zingali, R.B.; Guimaraes, J.A. Purification and characterization of a phospholipase $\mathrm{A}_{2}$ isoenzyme isolated from Lachesis muta snake venom. Biochem. Pharmacol. 2002, 63, 1589-1597.

54. Yamakawa, M.; Nozani, M.; Hokama, Z. Toxins: Animal, Plant and Microbial; Plenum Press: New York, USA, 1976; pp. 97-120.

(C) 2013 by the authors; licensee MDPI, Basel, Switzerland. This article is an open access article distributed under the terms and conditions of the Creative Commons Attribution license (http://creativecommons.org/licenses/by/3.0/). 